\title{
STRUCTURES AND HYDROCARBON PROSPECTS IN EMI FIELD, OFFSHORE NIGER DELTA
}

\author{
E.K. Nyantakyi ${ }^{1}$, T. Li $^{2}$, W. S. Hu ${ }^{3}$, J.K. Borkloe ${ }^{4}$ \\ ${ }^{1,2,3,4}$ School of earth Sciences, Yangzte University, Wuhan 430100, Hubei, China \\ emmanuelkwesinyantakyi@yahoo.com,ltm817@163.com,huwangshui@126.com,juliusborkloe1@yahoo.com
}

\begin{abstract}
The Niger Delta is ranked among the world's major hydrocarbon provinces in the world. Oil and gas in the Niger Delta are mainly trapped in sandstones and unconsolidated sands in the Agbada formation and the structural traps are not easy to map precisely because they are very slight, not obvious and very complicated. The main aim was to determine the structures and hydrocarbon prospects in Emi-field, off shore Niger Delta using seismic data integrated with well logs. Four (4) horizons namely $L_{1}, L_{2}, L_{3}$ and $L_{4}$ were selected and structural maps drawn for each of the horizons. Fault closures of high quality hydrocarbon prospects were identified and delineated. The integration of seismic data with well logs greatly improved the extent of accuracy and exactness of structural maps in hydrocarbon prospects and its development in Emi Field.
\end{abstract}

Key words: Structures, hydrocarbon prospects, Emi Field, Niger Delta

$* * *$

\section{INTRODUCTION}

The Niger Delta is ranked among the world's major hydrocarbon provinces in the world. It is the most important in the West African continental margin. Oil and gas in the Niger Delta are primarily produced from sandstones and unconsolidated sands mainly in the Agbada formation. The goal of oil and gas exploration is to identify and delineate structural traps suitable for profitably exploitable accumulations and delineate the extent of discoveries in field appraisals and development. These traps are very slight, not obvious and very complicated and are therefore not easy to map precisely. Major improvements in seismic and well logs have made it possible to map such structural arrangements with high degree of accuracy and exactness.

Seismic profiles provide almost a continuous lateral view of the subsurface by defining its geometry and providing an estimate of the acoustic impedance which is related to the formation densities and velocities.

However, vertical details are limited due to lengthy duration of the individual seismic wavelets and the occurrence of overlapping wavelets from closely spaced reflectors. Well logs are limited in their definition of lateral variation of subsurface parameters. Thus, the extent of accuracy in mapping complicated structural plays would be improved greatly by combining seismic data with well $\operatorname{logs}$ ([1]; [2]; [3]). In addition, the risk associated with finding oil and gas in very slight, not obvious and complicated structural places will be reduced tremendously since such integration will help to discern differences between poor and rich reservoirs and also greatly improve the extent of accuracy and exactness of the structural maps in hydrocarbon prospects and its development. In this research, 3-D seismic reflection data were integrated with well $\operatorname{logs}$ so as to characterize the subsurface geometry and also determine the structures and hydrocarbon prospects of the field.

\subsection{Location and Geological Setting of the Field}

The study field is located in the offshore depobelt of the Niger Delta (Figure 1) and covers an area of $58.24 \mathrm{~km} 2$ (Figure 2). The Niger Delta, situated at the apex of the Gulf of Guinea on the west coast of Africa, covers an area of about $75000 \mathrm{~km} 2$. The geology of the tertiary Niger Delta province has been described by several workers ([4]; [5]; [6]; [7]; [8]; [9]; [10]). Basement tectonics related to crucial divergence and translation during the late Jurassic and Cretaceous continental rifting probably determined the original site of the main rivers that controlled the early development of the Delta. The Cenozoic development of the delta is also believed to have taken place under approximate isostatic equilibrium. The main depocenter is thought to have been at the triple junction between the continental and oceanic crust where the delta reached a main zone of crustal instability. 

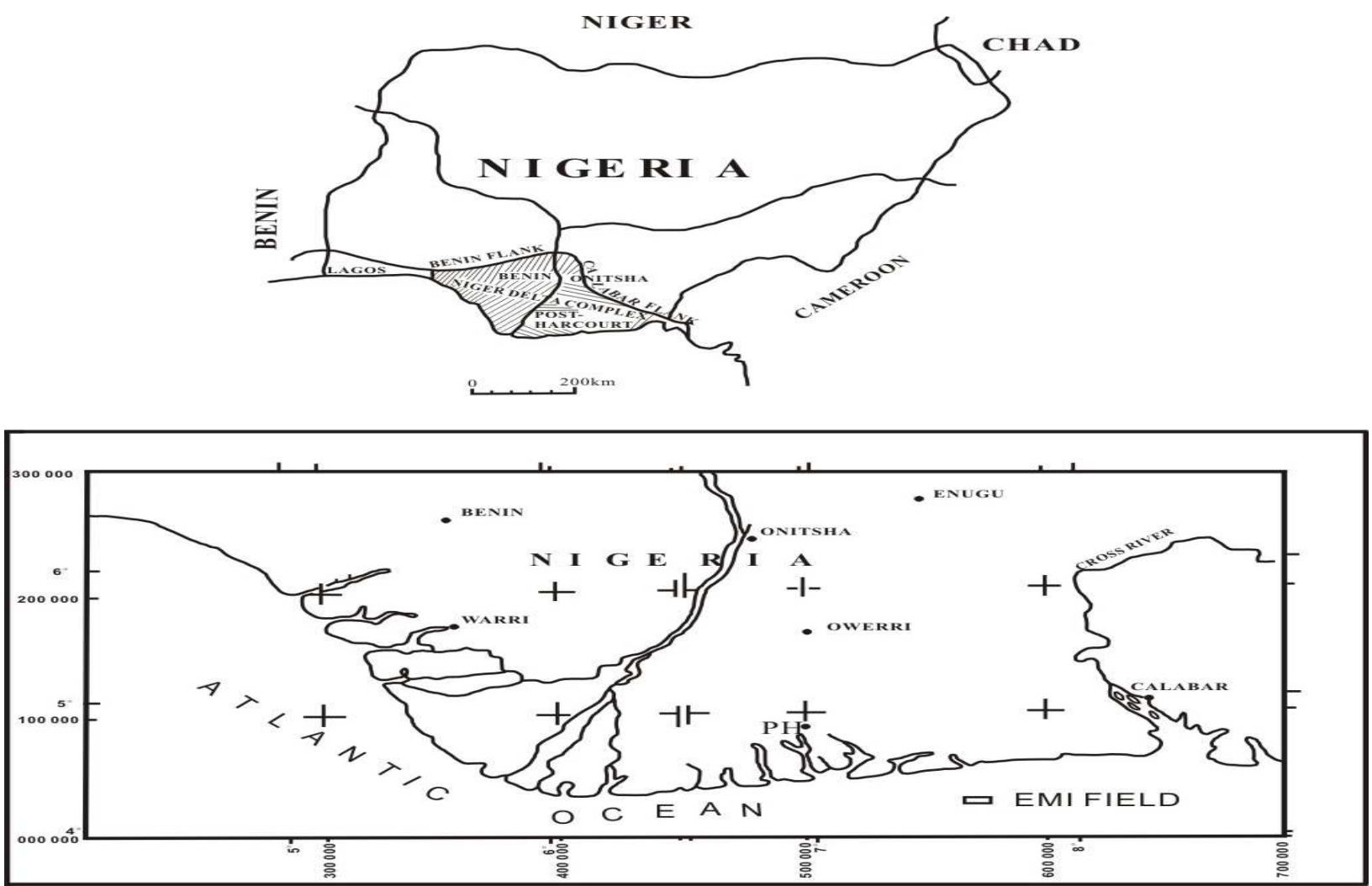

Figure 1: Map of Niger Delta showing the location of Emi Field.

The Niger Delta basin is located on the continental margin of the Gulf of Guinea in equatorial West Africa and lies between latitudes $4 \mathrm{o}$ and $7 \mathrm{oN}$ and longitudes $3 \mathrm{o}$ and $9 \mathrm{o} \mathrm{E}$ [11]. It ranks among the world's most prolific petroleum producing Tertiary deltas that together account for about $5 \%$ of the worlds' oil and gas reserves. It is one of the economically prominent sedimentary basins in West Africa and the largest in Africa [12]. Detailed studies on tectonics, stratigraphy, depositional environment, petrophysics, sedimentology and hydrocarbon potential are well documented in the literature ([4]; [6]; [8]; [13]; [9], [14]; [15]) among others.

The Niger Delta is a large arcuate delta of the destructive, wave-dominated type and is composed of an overall regressive clastic sequence which reaches a maximum thickness of about $12 \mathrm{~km}$ in the basin centre.

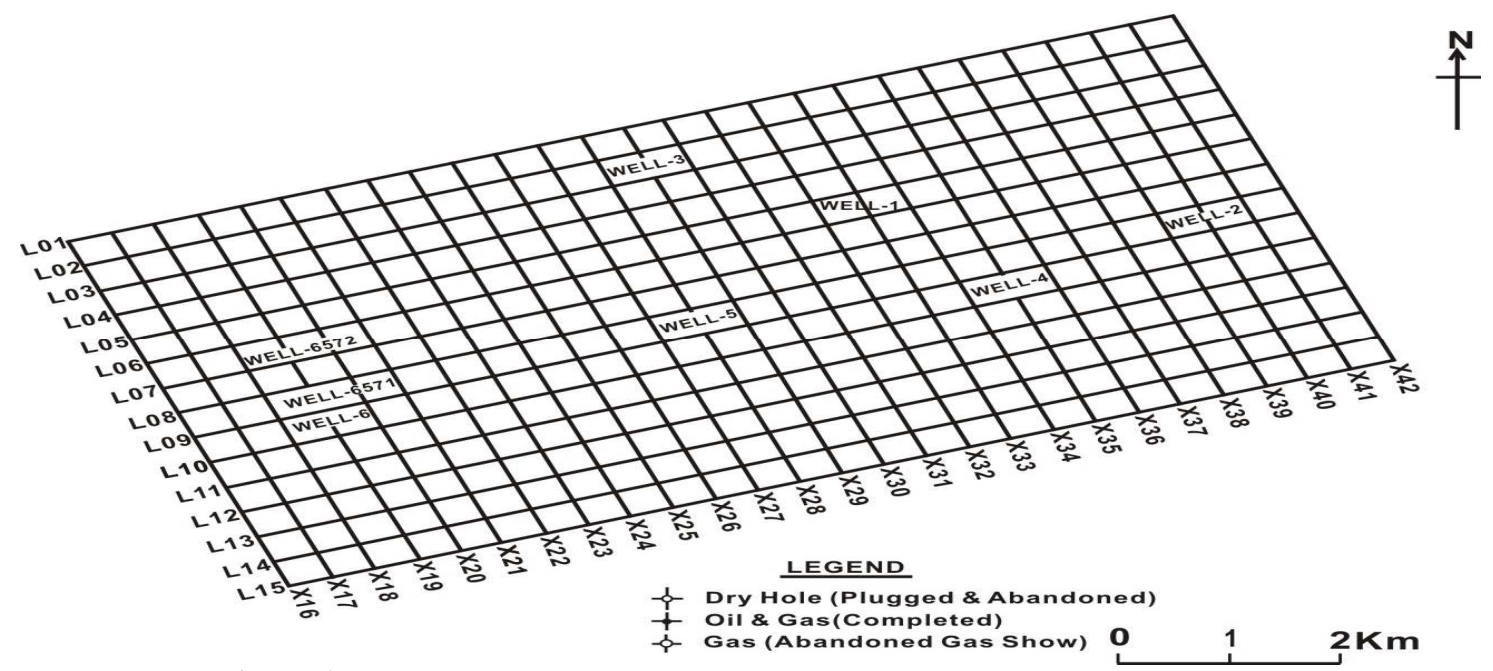

Figure 2: Base map of the study area showing well locations and seismic line. 
The Delta's sediments show an upward transition from marine pro-delta shales (Akata Formation) through a paralic interval (Agbada Formation) to a continental sequence (Benin Formation). These three sedimentary environments, typical of most deltaic environments, extend across the whole delta and ranges in age from early tertiary to resent. A separate member, the Afam clay member, of the Benin formation is recognized in the eastern part of the delta and is considered as an ancient valley fill formed in Miocene sediments. The formations are strongly diachronous [16] and cut across the time stratigraphic units which are characteristically S-shaped in cross-section. Most economically exploitable hydrocarbon in the delta is believed to be trapped within the Agbada formation.
Structurally, the Niger Delta shelf developed as a prograding extensional complex overlying a ductile substrate which probably composed largely of over pressure marine shales. The onshore growth fault systems have been described by [9] as a series of major growth fault bounded depobelts or megastructures thought to be transient basinal areas succeeding one another in space and time as the delta progrades southward. The extensional system is dominated by "tepee" structure in which landward-dipping growth faults intersects seaward dipping in complex interlocking fault networks (Figure 3).

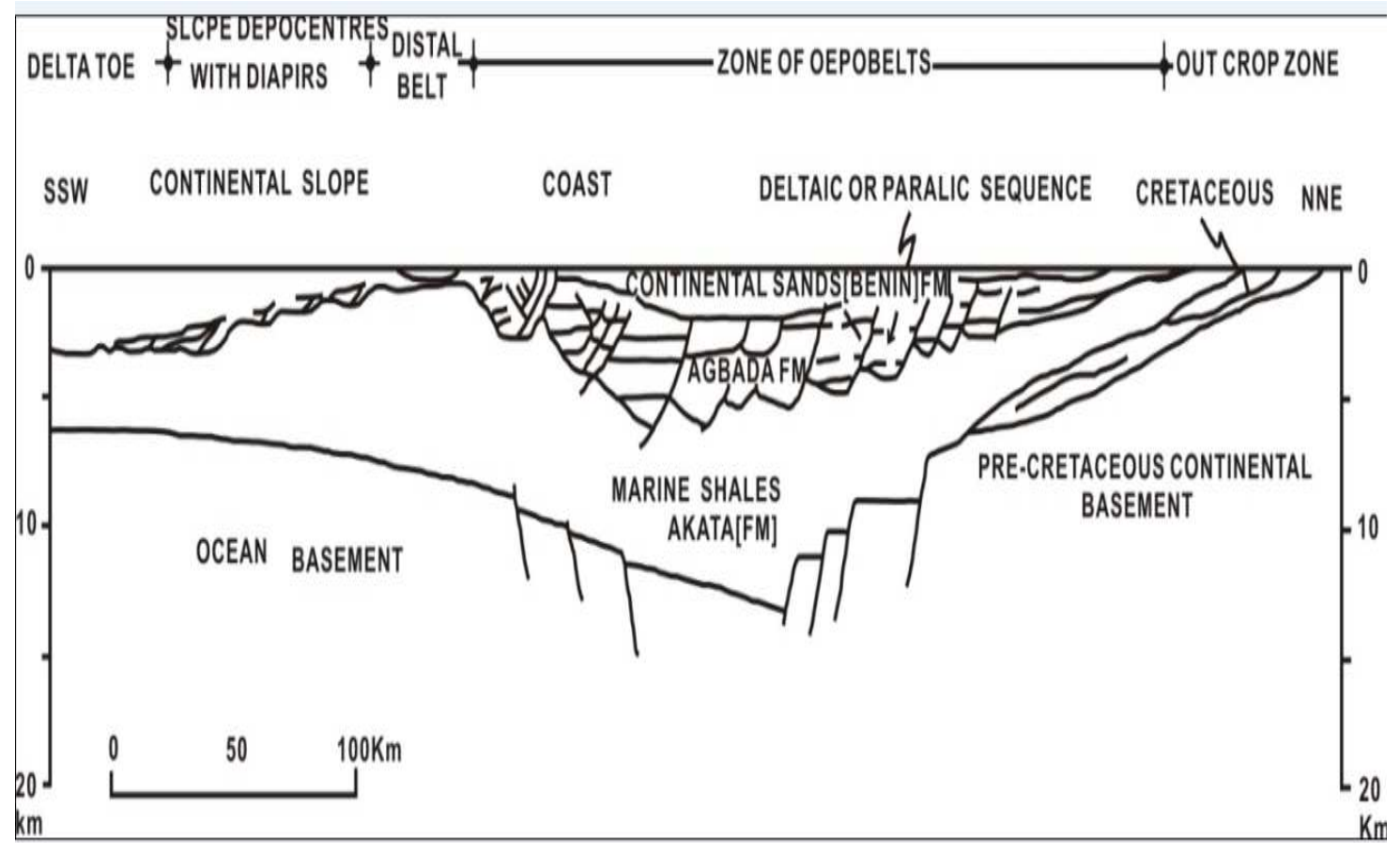

Figure 3: Schematic section through the axial potion of the Niger Delta showing the relationships of the tripartite division of the tertiary sequence to basement (Modified from [9]).

The most striking structural features of the Cenozoic Niger Delta complex are the syn-sedimentary structures which deform the delta largely beneath the Benin sand facies. These structures, regarded as the product of gravity sliding during the course of deltaic sedimentation, are polygenic in origin and their complexity increases generally in down delta direction [17]. The syn-sedimentary structures, called growth faults, are predominantly trending northeast to southwest and northwest to southeast [18]. Associated with these growth faults are rollover anticlines, shale ridges and shale diapers which are caused by shale upheaval ridges. Mud diapers are the most common and occur on the landward side of the growth faults restricting sedimentation on the up-thrown side of the faults and enhancing sedimentation on the down-thrown side. Most of the faults are listric normal; others include structure building growth faults, crestal faults, flank faults, counter-regional faults and antithetic faults.

In general, the offshore Niger Delta has the characteristic shelf slope break of growth fault modified ramp margins. The present day shelf is dominated by long counter regional faults. Further offshore, there exist a back-to-back fault trend along the shelf edge and upper slope. Down the slope, there are examples gentle folds, with thrust and diapers sometimes cutting the sea bed (Figure 4). 


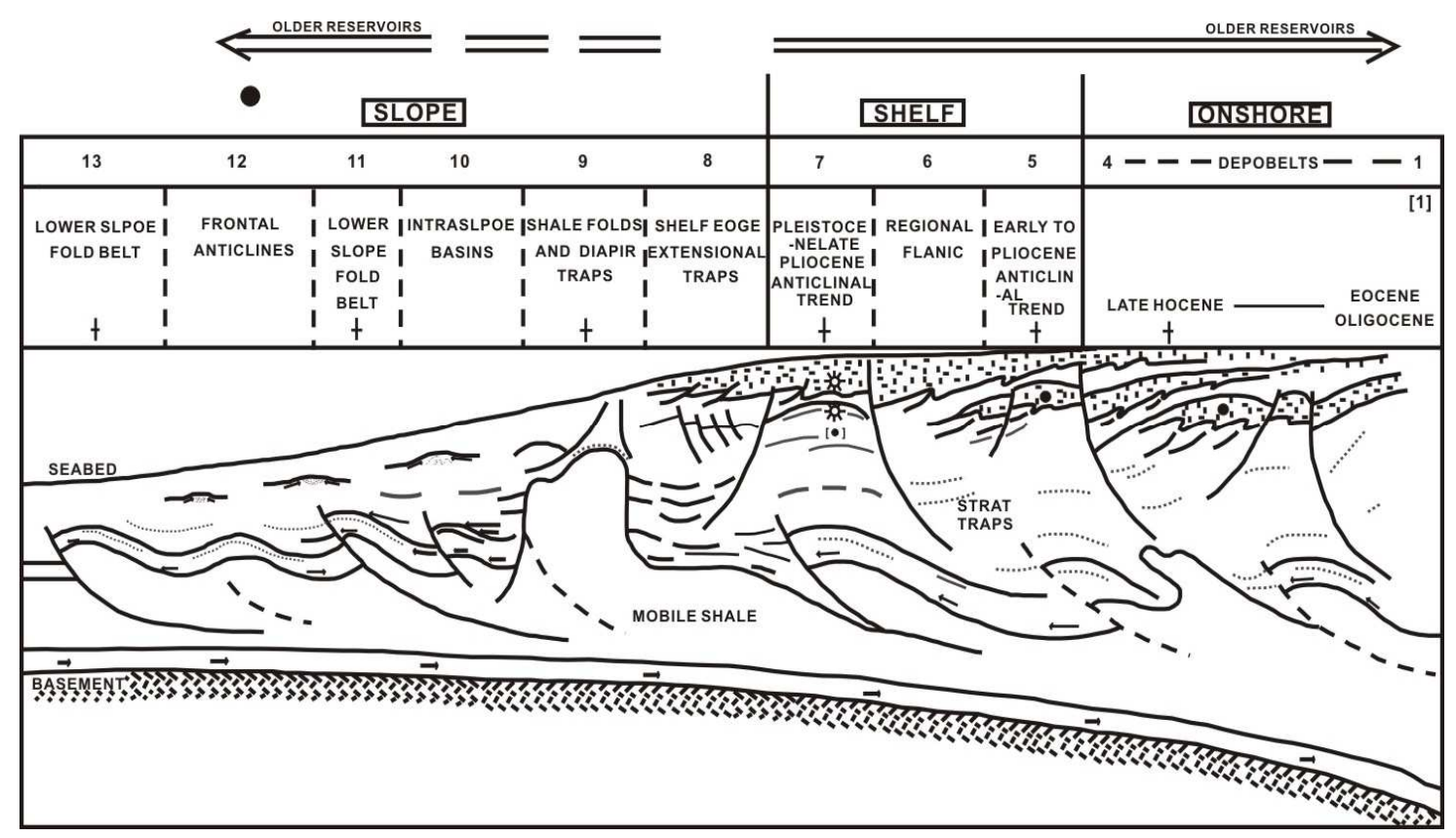

Figure 4: Niger Delta schematic structural profile of the deep water area characterized by listric extension faults gentle folds thrusts and diapirs (Modified from [19]).

Oil and gas are mainly trapped by roll over anticlines and fault closures. Hydrocarbon distribution in the Niger Delta is complex with gas-to-oil ratio generally increasing southward away from the depocentre within a depobelts [8] and is primarily controlled by thermal history of the source rocks, source rocks quality, migration and sealing quality. In addition, the timing of traps formation could be a factor that controls the distribution of hydrocarbon [20]

Trap arrangement in the deep water Nigeria is controlled by gravity driven system of linked extensional growth faults and compressional toe thrusts initiated during the Paleogene, when the modern Niger delta was formed [10]. Most of the reservoir facies in the offshore Niger Delta are related to an aggrading lowstand complex where a slow relative rise in the sea levels allows sediment input to keep pace with the creation of accommodation space over a long period of time. A thick expanding edge of coarse clastics is trapped on the shelf behind the counter regional faults and most of the sediments are therefore, deposited on the shelf, indicating that the sand content and gross sediment input reduces dramatically with increasing distance from provenance.

\section{METHODOLOGY}

\subsection{Seismic and Well Logs Data}

The different datasets employed in this research were provided by the Exxon Mobil Producing Nigeria Unlimited, Lagos,
Nigeria and covered an area of $58.24 \mathrm{~km} 2$ on a scale of 1:250000. These included 3-D Seismic profiles, composite well logs comprising mainly spontaneous potential, gamma ray, resistivity, density and neutron logs of the four wells (WELL-1, WELL-3, WELL-4 and WELL-5). Twenty-seven of the seismic lines were cross-lines shot parallel to the dip direction and the other fifteen were in-lines which were shot parallel to the strike direction. The spacing between the seismic section for both the in-lines and cross-lines was $400 \mathrm{~m}$ as shown in Figure 2.

\subsection{Horizons Selection and Fault Identification}

Horizons within the well logs that showed hydrocarbon prospects were selected for mapping. Four horizons namely L1, L2, L3 and L4 were chosen and correlated through all the seismic sections. Major faults were identified mainly on abrupt termination of reflection events and marked on the cross-lines. Fault traces at all levels was consistent. The horizons were then tied at their intersection points in order to ensure consistency in all the lines of intersections and in all the seismic sections which covered the entire survey area. The analysis was rechecked in areas where there were misties and the misties corrected.

\subsection{Structural Maps}

The chosen horizons were digitized using a scale appropriate to the seismic sections and structural maps were then produced 
for each of the horizons. During contouring, the variable nature of the seismic signals as well as the varying structural features of rock deformation was taken into consideration. The fault traces were posted to the structural maps produced. The fault throws and directions obtained from the seismic sections were correlated with well logs.

\section{RESULTS AND DISCUSSION}

\subsection{Seismic Interpretations and Fault Identification}

Migration and tying of seismic sections were undertaken at the intersection point between the cross-lines and in-lines. Counter regional growth faults F1, F2, F3, F4, F5 and F6 were the major faults identified on the seismic records. These counter regional growth faults were trending west-east and dipping south-east. Two regional growth faults $F^{\prime} 1$ and $F^{\prime} 2$ selected were trending north-south and dipping south-west. The throw of the major faults ranged from 46 to $79 \mathrm{~m}$ while that of the minor faults ranged from 24 to $36 \mathrm{~m}$. This throw which could have produced migration pathway for hydrocarbon was recognized.

\subsection{Structures and Hydrocarbon Prospects}

The horizons mapped were laterally continuous on the seismic records and formed a closed loop along the tie lines. Figures 5 to 8 displayed the structural maps of the horizons L1, L2, L3 and L4 mapped respectively. These structural maps showed a system of rollover anticlines associated with growth faults. The faults appeared crescent-shaped with the concave side being towards the down-thrown block. The synthetic and antithetic faults showed less curvature in the horizontal plane and were generally steeper in the vertical plane. The throw of the major faults ranged from 40 to $60 \mathrm{~ms}$ corresponding to 46 $\mathrm{m}$ to $79 \mathrm{~m}$. The growth faults were sub-parallel to one another and stroked in the west-east direction. The faults were sealing on the up-thrown side of the fault zone where most of the hydrocarbons could be trapped.

Horizons L1, L2, L3 and L4 revealed faulted and folded anticlinal closures (I and II) and fault assisted closures (III, IV, V, and VI). The structural closures I and II closed by $121 \mathrm{~m}$ respectively. The faults served as conduits for hydrocarbon into the structural closures and the reservoir units at large. Cross-sections through its structural maps also suggested a system of growth faults, roll over anticlines and folding. However, structural map of L4 revealed unconformities.

These anticlinal closures were identified as good traps for hydrocarbon prospects. Trapping of hydrocarbon by means of simple closure was independent of the presence of faults and trapping in fault closures was assisted by sealing faults in which the fault plane and the sediments dipped in opposite directions.

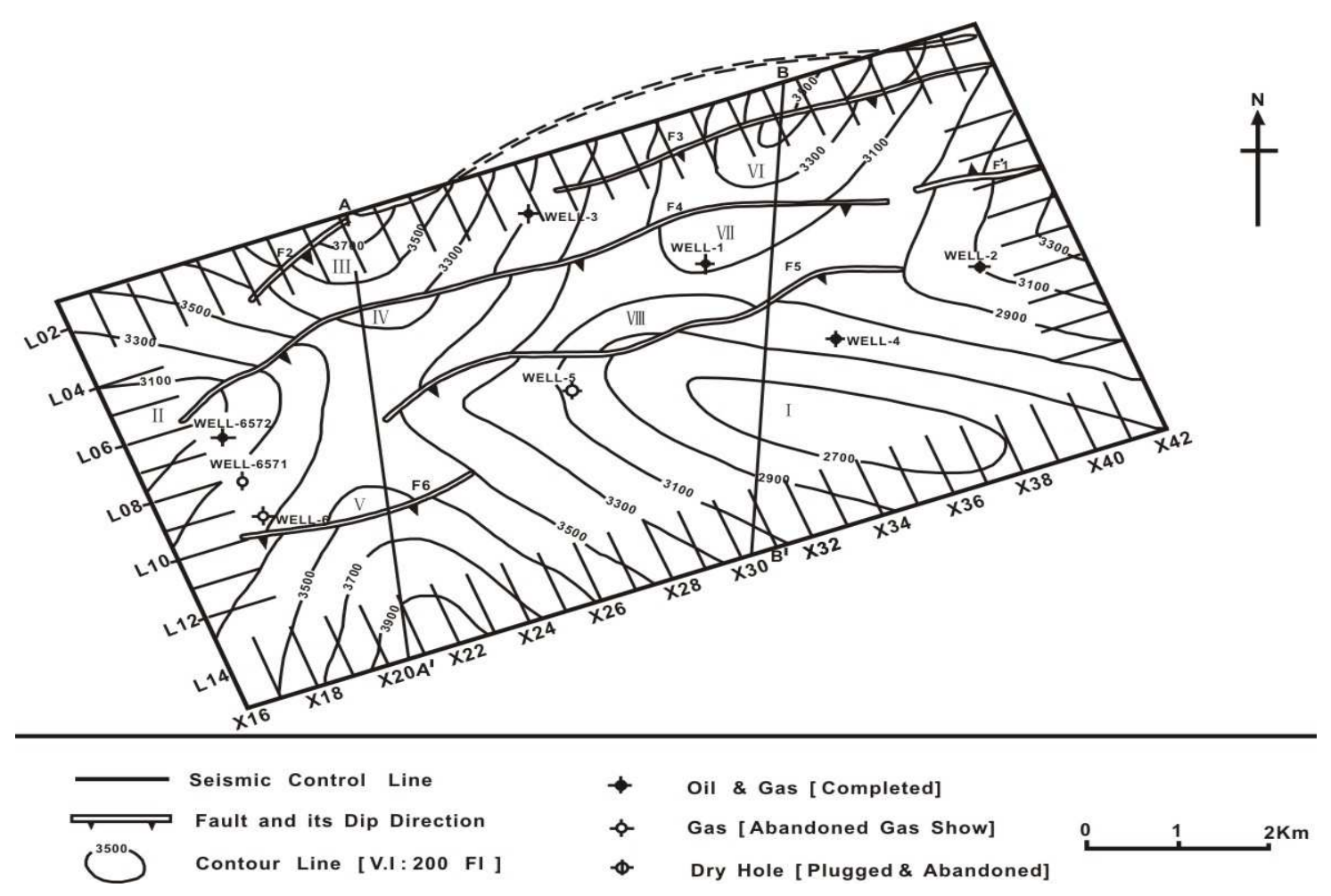

Figure 5: Structural map of horizon L1. 


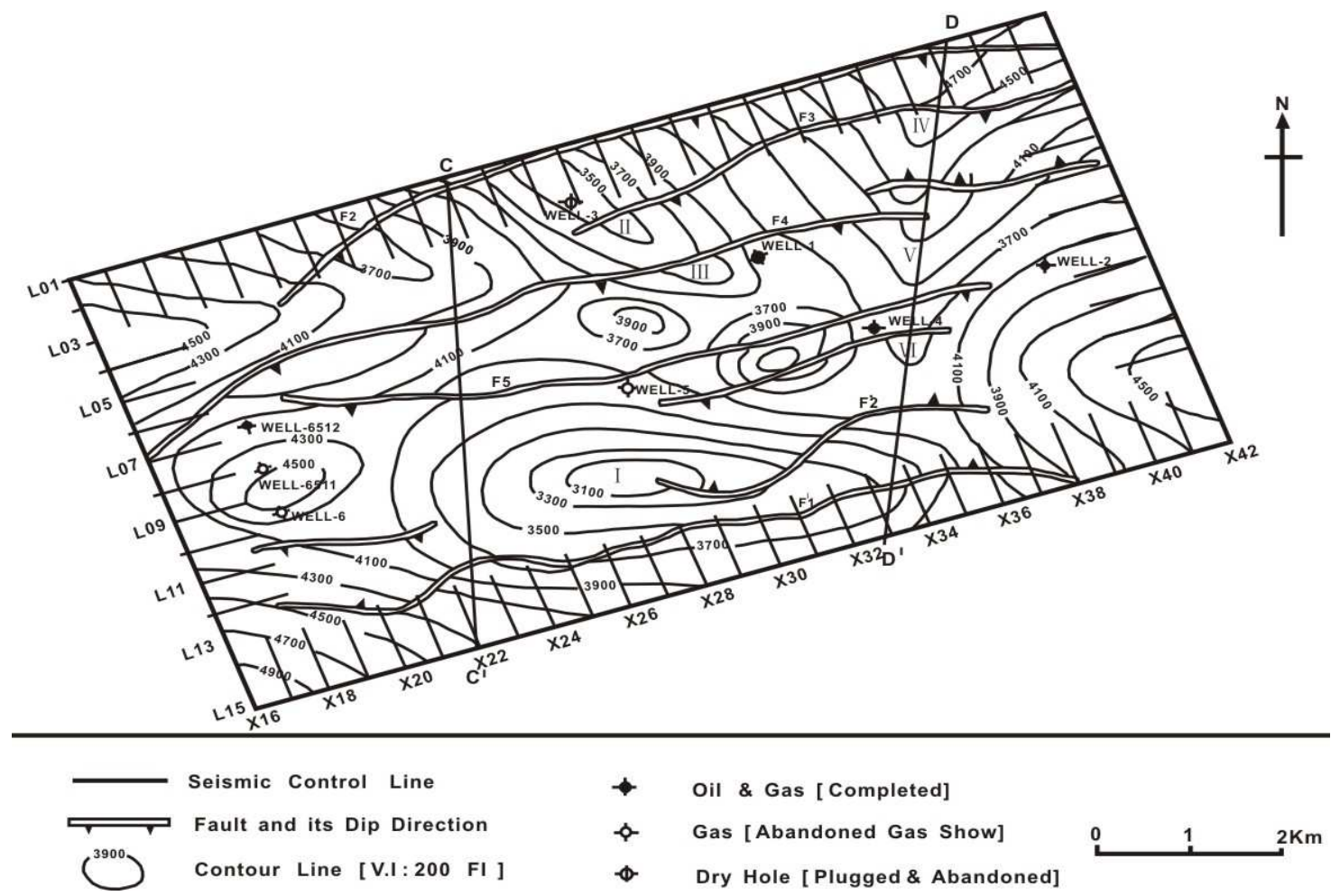

Figure 6: Structural map of horizon L2

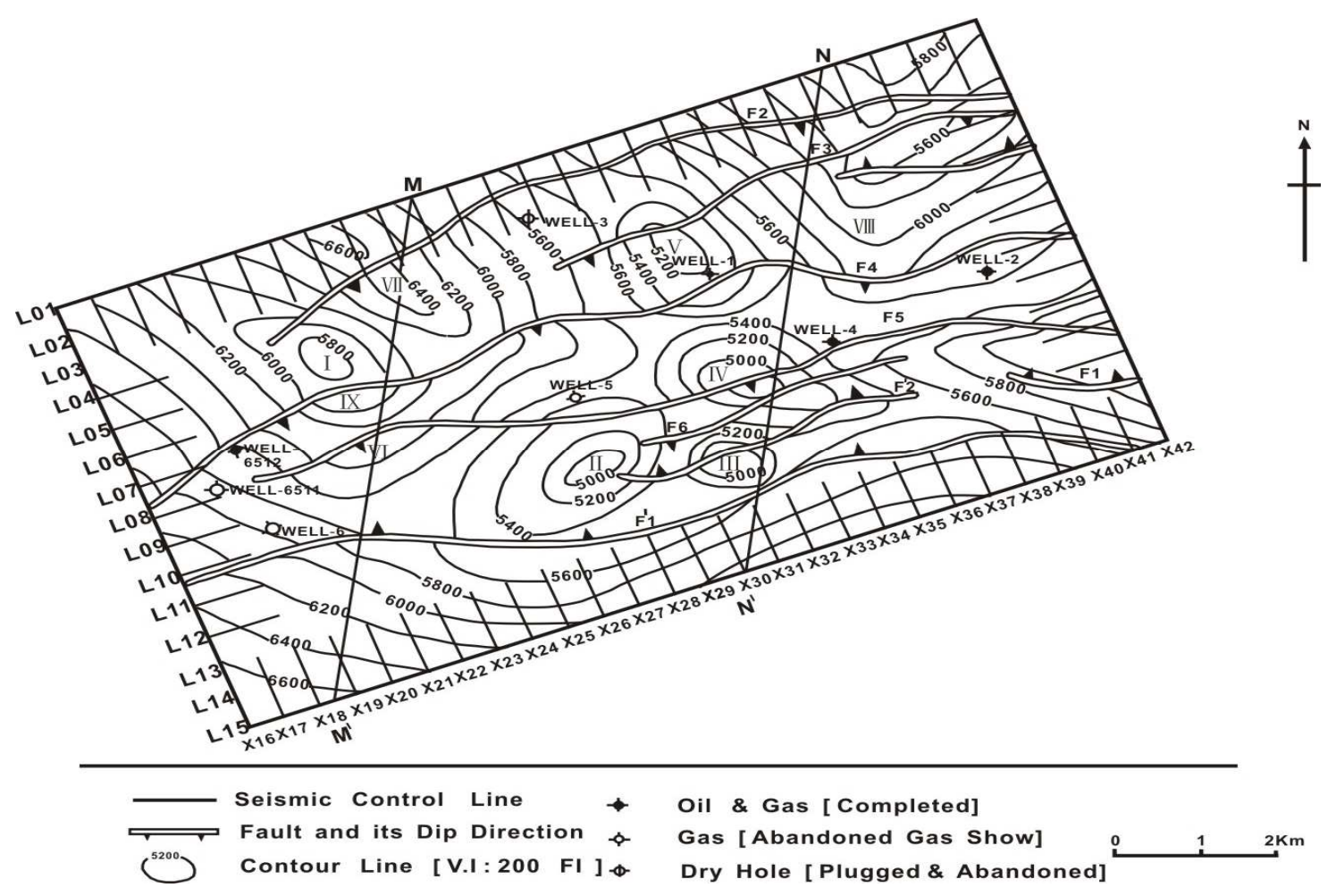

Figure 7: Structural map of horizon L3 


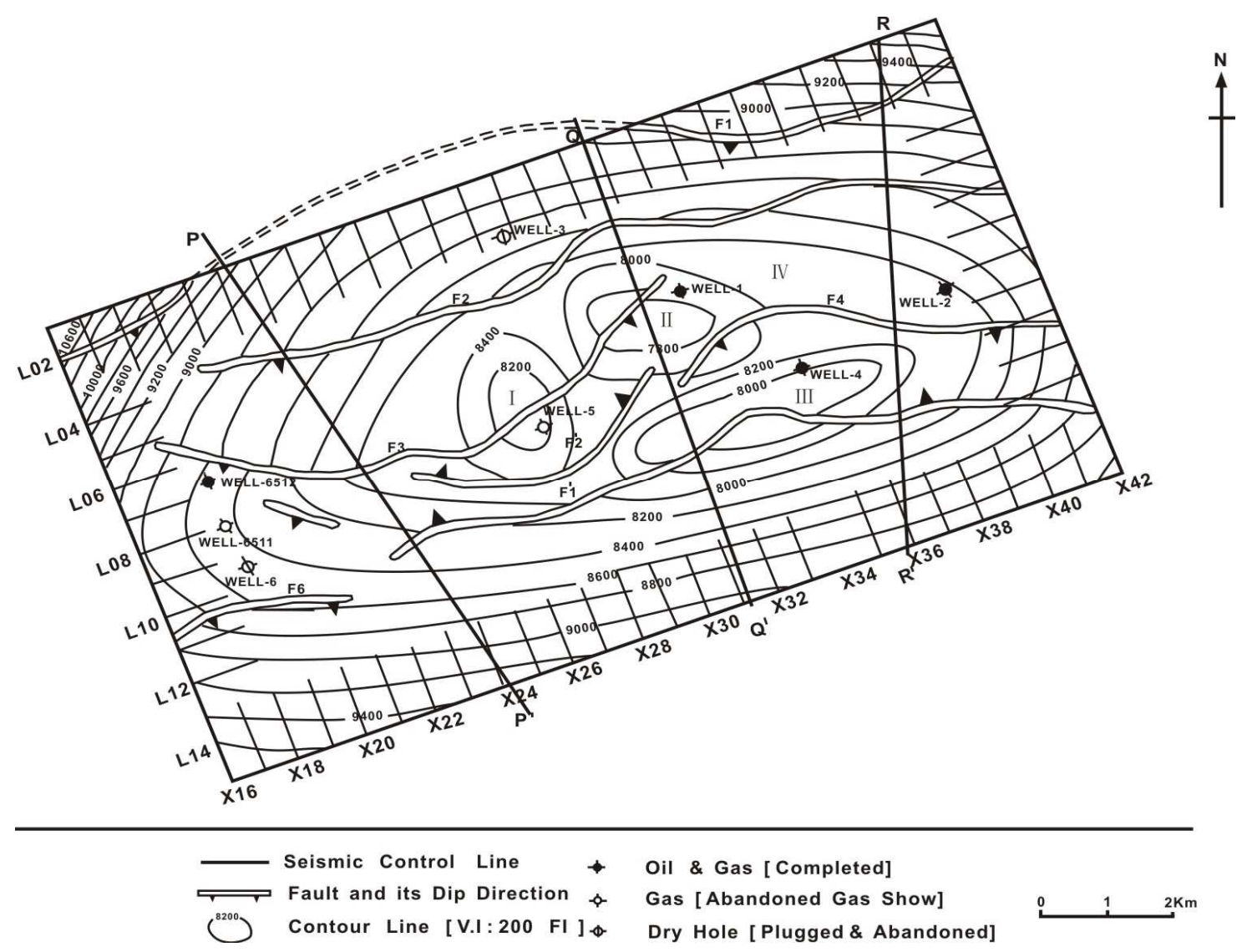

Figure 8: Structural map of horizon L4

\section{CONCLUSIONS}

The four (4) horizons mapped were all within the Agbada formation since most of the hydrocarbon was believed to be trapped in the Niger Delta. Anticlinal closures and fault assisted closures regarded as good hydrocarbon prospect areas were delineated in the structural maps. The integration of seismic data and well logs proved to be a useful and important technique in structural mapping and was successful in defining the subsurface geometry, and determining the structure and hydrocarbon trapping potential of Emi field. The technique proved to be very useful in structural mapping. Hydrocarbon prospect areas were delineated in the structural maps produced. The growth faults acted as conduits for hydrocarbon from the underlying Akata formation.

\section{ACKNOWLEDGEMENTS}

The authors would like to acknowledge the management of Kumasi Polytechnic, Kumasi headed by the Rector Prof. N.N.N. Nsowah-Nuamah, for providing financial assistance and also the management and staff of ExxonMobil, Lagos, Nigeria, for providing 3-D seismic data and well logging data.

\section{REFERENCES}

[1]. Barde JP, Chambertain P, Gralla P, Harwijanto J, Marsky J, Schroeter T (2000). Explaining a complex hydrocarbon system in the Permo- Triassic of the precaspian basin by integration of independent models. Abstracts, 62nd European Association of Geoscientists and Engineers Conference and Technical Exhibition, 2: (P.021), P. 4

[2]. Barde JP, Gralla P, Harwijanto J, Marsky J (2002). Exploration at the eastern edge of the prescapian basin impact of data integration on Upper Permian and Trasic prospectivity. Am. Assoc. Petrol. Geol. Bull., 86: 399-415.

[3]. Adejobi AR, Olayinka AI (1997). Stratigraphy and hydrocarbon potential of the Opuama channel complex area, western Niger delta. Nig. Ass. of petrol. Expl. (NAPE) Bull., 12: $1-10$

[4]. Short, K.C. and Stauble, A. J. 1967. outline of the geology of Niger Delta, American Association of Petrroleum Geologists Bulletin, 51 p. 761-779

[5]. Weber KJ (1971). Sedimentological aspect of oil fielding the Niger Delta. Geol. Minjbouw, 50: 559-576. 
[6]. Weber, K.J. and Daukoro, E.M. 1975. Petroleum geological aspects of the Niger Delta. Tokyo, 9th world Petroleum Congress Proceedings, 5 ( 2), p. 209-221

[7]. Weber KJ, Mandi J, Pilaar WF, Lehner E, Precious RG (1978). The role of faults in hydrocarbon migration and trapping in Nigeria growth fault structures. 10th Annual Offshore Technology Conference Proceedings, 4: 2643-2653.

[8]. Evamy, B.O., Herembourne, j., Kameline, P., Knap, W.A., Molloy, F.A. and Rowlands, P.H. 1978. Hydrocarbon habitat of Tertiary Niger Delta, American Association of Petroleum Geologists Bulletin, 62, p.1-39

[9]. Doust H, Omatsola E (1990). Niger Delta in divergent/passive margin basins, in J. D. Edwards and P. A. Santogrossied, eds., Am. Assoc. Petrol. Geol. Memoir, 48: 201-238.

[10], Haack RC, Sundararaman P, Diedjomahor JO, Xiao H, Gant NJ, May ED, Kelsch K (2000). Niger Delta petroleum systems, Nigeria, in M. R. Mello and B. J. Katz, eds., Petroleum systems of South Atlantic margins: Am. Assoc. Petrol. Geol. Memoir, 73: 213-231.

[11]. Whiteman, A., 1982, Nigeria: Its Petroleum Geology, Resources and Potential: London, Graham and Trotman, 394 p. [12]. Reijers, T.J.F., 1996. Selected Chapters on Geology , SPDC of Nigeria, Copporate Reprographic Services, Warri, $197 \mathrm{p}$

[13]. Knox, G. J. \& Omatsola, M. E. (1989):Development of the Cenozoic Niger Delta in terms of the escalator regression model and impact on hydrocarbon distribution, In:

[14]. Nton, M.E. and Adebambo, B.A., 2009 Petrophysical evaluation and depositional environments of reservoir sands of X- field, offshore Niger delta ., Mineral Wealth Vol. 150 pp 112

[15]. Nton, M.E. and Adesina, A. D., 2009. Aspects of structures and depositional environment of sand bodies within tomboy field, offshore western Niger Delta, Nigeria RMZ Materials and Geoenvironment, Vol. 56, No. 3, pp. 284-303

[16]. Murat RC (1970). Stratigraphy and Paleogeography of the Cretaceous and Lower Tertiary in Southern Nigerian. 1st Conference on African Geology Proceedings, Ibadan University Press, pp. 251-266.

[17]. Merki PJ (1972). Structural geology of the Cenozoic Niger Delta: 1st Conference on African Geology Proceedings, Ibadan University Press, pp. 635-646.

[18]. Hosper J (1971). The geology of the Niger Delta area, in the Geology of the East Atlantic continental margin, Great Britain, Institute of Geological Science, Report, 70(16): 121141

[19]. Ojo AO (1996). Pre-drill prospect evaluation in deep water Nigeria. Nig. Assoc. Petrol. Explo. Bull., 11: 11-22.

[20]. Chukwueke CC (1997). Factors controlling hydrocarbon distribution in the central swamp deposit of the Niger Delta. Nig. Assoc. Petrol. Explorat. Bull., 12: 41-45.

\section{BIOGRAPHIES}

Emmanuel Kwesi Nyantakyi is a $\mathrm{PhD}$ Student at the Structural Geology Department, School of Earth Sciences, Yangtze University, Wuhan-China. He holds an MSc. in Road and Transportation Engineering. His research areas are Oil and Gas Storage and Transportation, Structural Geology, Seismic Interpretation, Petroleum Geology and Geochemistry. He is a Member of American Association of Petroleum Geologists (AAPG).

Li Tao is a Lecturer at the Geology Department, School of Earth Sciences, Yangtze University, Wuhan-China. He holds a $\mathrm{PhD}$ in Structural Geology and his research areas are Structural Geology, Petroleum Geology and Seismic Interpretation.

Wangshui Hu is a professor of Structural Geology, School of Earth Sciences, Yangtze University, Wuhan-China. He holds a $\mathrm{PhD}$ in Structural Geology and his research areas are Structural Geology, Sedimentology, Seismic Interpretation and Petroleum Geology.

Julius Kwame Borkloe is a PhD Student at the Structural Geology Department, School of Earth Sciences, Yangtze University, Wuhan-China. He holds an MSc. in Structural Engineering. His research areas are Geophysics, Structural Geology, Seismic Interpretation and Geochemistry. He is a Member of American Association of Petroleum Geologists (AAPG) and Ghana Institution of Engineers (GhIE) 